\title{
Cyclic behavior of GFRP strengthened infilled RC frames with low and normal strength concrete
}

https://doi.org/10.1515/secm-2017-0060

Received February 15, 2017; accepted March 26, 2018; previously published online August 8, 2018

Abstract: This paper presents the experimental behavior of plane, non-strengthened and glass fiber reinforced polymer (GFRP) strengthened infilled reinforced concrete (RC) frames with low strength concrete (LSC) and normal strength concrete (NSC) under lateral reversed cyclic loading. For this purpose, eight full-scale, onebay, one-storey plane and infilled (brick and aerated concrete blocks which are commonly used in RC construction) RC frames with LSC and NSC were produced and in-plane lateral loading tests were carried out. Test results indicate that infill walls considerably change the behavior of frames by increasing rigidity and load carrying capacity. By contrast, GFRP fabric used for strengthening of infilled RC frames improves ductility, load carrying and energy dissipation capacity of infilled frames with LSC and NSC as well. After all the test results were evaluated together, a GFRP strengthened brick infilled frame demonstrated the best performance under cyclic lateral loading.

Keywords: aerated concrete; brick; cyclic loading; GFRP strengthening; RC infilled frame.

\section{Introduction}

As is well known, while structural analysis of frame system structures under lateral loads is performed, the contribution and/or effects of infill walls are neglected. However, the recent earthquakes, and experimental and theoretical studies have depicted that infill walls substantially affect the behavior of reinforced concrete (RC) buildings with a frame system under lateral loads. Indeed, infill walls change stiffness, ductility, damping ratio, period,

\footnotetext{
*Corresponding author: Mehmet Emin Arslan, Duzce University, Technology Faculty, Department of Civil Engineering, Duzce, Turkey, e-mail: mehmeteminarslan@duzce.edu.tr Ahmet Durmuş: Nuh Naci Yazgan University, Engineering Faculty, Department of Civil Engineering, Kayseri, Turkey

Metin Hüsem: Karadeniz Technical University, Engineering Faculty, Department of Civil Engineering, Trabzon, Turkey
}

Ә Open Access. (cc)BY @ 2019 Walter de Gruyter GmbH, Berlin/Boston failure mode and load carrying capacity of the frame system RC buildings [1].

Especially in developing countries in the world, a large part of the existing buildings has been designed in accordance with former standards and often consists of insufficient materials and section properties. As a result, many existing buildings have deficient lateral load resistance, insufficient energy dissipation and can rapidly lose their strength during earthquakes, leading to collapse [2]. The retrofit of seismically deficient structures is one of the solutions to enhance ductility, load carrying and energy dissipation capacity. Recently, the use of fiber reinforced polymer (FRP) composite materials has been proposed as an alternative solution for strengthening of seismically deficient buildings [3, 4]. FRP materials have advantages over other traditional strengthening techniques (cement and epoxy injection steel or RC coating and external prestressing) such as high strength to weight ratio, high resistance to corrosion, excellent durability, and ease and speed of in-place application [5].

Numerous tests have been carried out by researchers to examine the behavior of structural members strengthened by using FRP sheets. In these studies, researchers investigated the effect of the type, amount, and pattern of FRP [6$16]$. Owing to these test results, specifications $[17,18]$ and numerical models have been developed to estimate the seismic behavior of deficient and strengthened RC buildings [2]. However, most of these studies have been fulfilled using carbon fiber reinforced polymer (CFRP) sheets.

When the technical literature is surveyed, few studies are encountered about the effects of glass fiber reinforced polymer (GFRP) sheets on structural members [19-24]. Thus, the effects of GFRP sheets on the behavior of infilled RC frames are undetermined. Under the circumstances, the main objective of the current study is to comparatively investigate the behavior of plane and full-scale infilled $\mathrm{RC}$ frames with low strength concrete (LSC) and normal strength concrete (NSC), strengthened by using GFRP under lateral reversed cyclic loading. The reason for choosing LSC for comparison is to reflect the behavior of existing seismically deficient buildings. At the end of the study, drift ratio, lateral load carrying and energy dissipation capacity, stiffness degradation and displacement ductility of the RC frame were determined and suggestions are made. 


\section{Materials and methods}

As it was already mentioned, the experimental behavior of plane and strengthened infilled RC frames under lateral reversed cyclic loading was investigated. For this purpose, eight full-scale, one-bay, one-storey, plane frames, RC frames infilled with brick and aerated concrete blocks were produced using LSC and NSC. Thereafter, GFRP strengthening was applied to one of each series of infilled $\mathrm{RC}$ frames. Labeling of strengthened and non-strengthened RC frames is given in Table 1.

\subsection{Materials}

Mixture proportions of NSC and LSC used for producing the frames are given in Table 2. CEM II/B-M (P-LL) 32.5-R

Table 1: Labeling of reinforced concrete (RC) frame test specimens.

\begin{tabular}{ll}
\hline Labeling & Description of the specimens \\
\hline PRCF-1 & Plane RC frame with LSC \\
PRCF-2 & Plane RC frame with NSC \\
RCF-1 & $\begin{array}{l}\text { Brick infilled RC frame with LSC } \\
\text { Brick infilled RC frame with LSC and strengthened } \\
\text { RCF-2 }\end{array}$ \\
using GFRP \\
RCF-3 & $\begin{array}{l}\text { Brick infilled RC with using NSC } \\
\text { RCF-4 }\end{array}$ \\
Brick infilled RC frame with NSC and strengthened \\
using GFRP
\end{tabular}

GFRP, glass fiber reinforced polymer; LSC, low strength concrete; NSC, normal strength concrete; RC, reinforced concrete. cement was used and the dosage was kept constant at $370 \mathrm{~kg} / \mathrm{m}^{3}$ with $0.5 \mathrm{~W} / \mathrm{C}$ ratios and $225 \mathrm{~kg} / \mathrm{m}^{3}$ with $0.9 \mathrm{~W} / \mathrm{C}$ ratios for NSC and LSC, respectively. Characteristic compressive strength of NSCs and LSCs was determined as 25.14 MPa and 9.75 MPa and elasticity modulus of the concretes was determined as 28,670 MPa and 11,245 MPa, respectively.

Producing infill walls was fulfilled using $13.5 \times 19 \times 19 \mathrm{~cm}$ horizontal coring bricks and $60 \times$ $25 \times 19 \mathrm{~cm}$ aerated concrete blocks. Some mechanical and physical properties of horizontal coring bricks and aerated concrete blocks are given in Table 3.

\subsection{Details of test specimens and strengthening technique}

Dimensions and reinforcement details of the test frames are given in Figure 1. Reinforcement of the test specimens is detailed in accordance with the Turkish Seismic Code [25]. Dimensions of frame and foundation are given in $\mathrm{cm}$. Also, rebar diameters are shown in $\mathrm{mm}$. Some mechanical properties of steel rebars are given in the Table 4. The reinforcement ratio of the beam is 0.005 and 0.015 for columns. Dimensions of the columns and beams are $250 \mathrm{~mm} \times 250 \mathrm{~mm}$. In addition, $50 \mathrm{~mm}$ and $100 \mathrm{~mm}$ stirrup spacings were used for the confinement zone and mid zone, respectively. These stirrup spacing values are $75 \mathrm{~mm}$ and $150 \mathrm{~mm}$ for beam elements. Figure 2 also illustrates the process of infill wall and concrete plaster applications.

GFRP sheets have been used for the strengthening of the infilled RC frames. Some physical and mechanical

Table 2: Mixture proportions of normal strength concrete (NSC) and low strength concrete (LSC).

\begin{tabular}{|c|c|c|c|c|c|c|c|c|}
\hline \multirow{3}{*}{$\begin{array}{l}\text { Mixture } \\
\text { proportions }\end{array}$} & \multicolumn{5}{|c|}{ Aggregates $\left(\mathrm{kg} / \mathrm{m}^{3}\right)$} & \multirow{3}{*}{$\begin{array}{r}\text { Saturation } \\
\text { water } \\
\left(\mathrm{kg} / \mathrm{m}^{3}\right)\end{array}$} & \multirow{3}{*}{$\begin{array}{r}\text { Mixing } \\
\text { water } \\
\left(\mathrm{kg} / \mathrm{m}^{3}\right)\end{array}$} & \multirow{3}{*}{$\begin{array}{l}\text { Cement } \\
\left(\mathrm{kg} / \mathrm{m}^{3}\right)\end{array}$} \\
\hline & \multicolumn{5}{|c|}{ Sieve size $(\mathrm{mm})$} & & & \\
\hline & $0.5-1.0$ & $1.0-2.0$ & $2.0-4.0$ & $4.0-8.0$ & $8.0-16.0$ & & & \\
\hline NSC & 265.50 & 265.50 & 265.50 & 442.50 & 531.00 & 7.080 & 185 & 370 \\
\hline LSC & 265.35 & 265.35 & 265.35 & 442.25 & 530.40 & 7.076 & 225 & 250 \\
\hline
\end{tabular}

Table 3: Some mechanical and physical properties of brick and aerated concrete blocks.

\begin{tabular}{lrrrr}
\hline Infill wall material & $\begin{array}{r}\text { Dimensions } \\
(\mathbf{c m})\end{array}$ & $\begin{array}{r}\text { Average compressive } \\
\text { strength }(\mathbf{M P a})\end{array}$ & $\begin{array}{r}\text { Modulus of } \\
\text { elasticity }(\mathbf{M P a})\end{array}$ & $\begin{array}{r}\text { Unit weight } \\
\left(\mathbf{k g} / \mathbf{m}^{3}\right)\end{array}$ \\
\hline Horizontal coring brick & $13.5 \times 19 \times 19$ & 5.2 & 2000 & 600 \\
Aerated concrete block & $60 \times 25 \times 19$ & 3.3 & 1095 & 500 \\
\hline
\end{tabular}




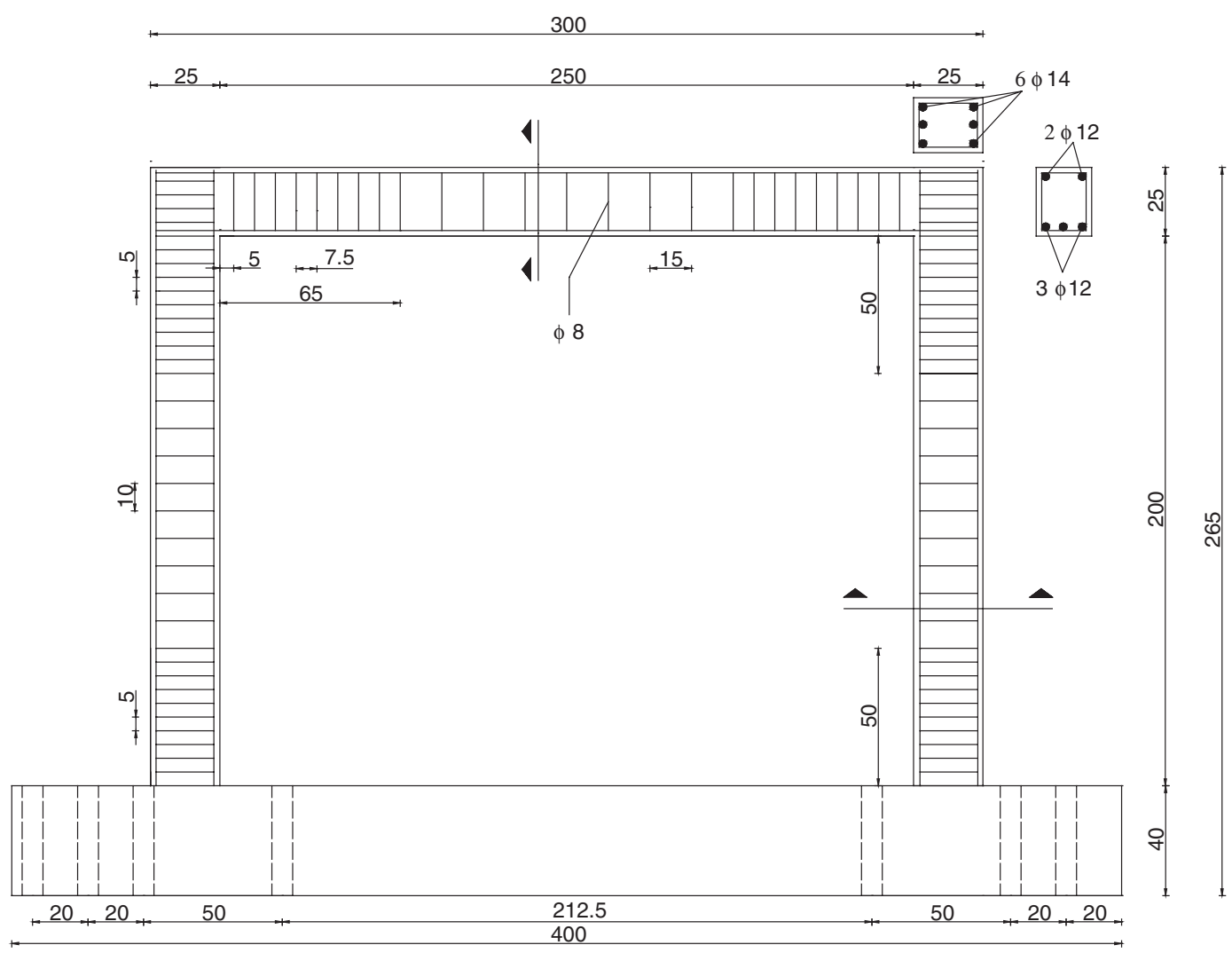

Figure 1: Dimensions and reinforcement details of the test frames.

Table 4: Some mechanical properties of steel rebars used in the test specimens.

\begin{tabular}{lrrrrr}
\hline $\begin{array}{l}\text { Rebar } \\
\text { diameter } \\
(\mathrm{mm})\end{array}$ & $\begin{array}{r}\text { Average } \\
\text { yield } \\
\text { strength } \\
(\mathrm{MPa})\end{array}$ & $\begin{array}{r}\text { Average } \\
\text { tensile } \\
\text { strength } \\
(\mathrm{MPa})\end{array}$ & $\begin{array}{r}\text { Average } \\
\text { rupture } \\
\text { strength } \\
(\mathbf{M P a})\end{array}$ & $\begin{array}{r}\text { Yield } \\
\text { strain } \\
(\%)\end{array}$ & $\begin{array}{r}\text { Rapture } \\
\text { strain } \\
(\%)\end{array}$ \\
\hline 8 & 510 & 570 & 490 & 0.23 & 23 \\
12 & 480 & 555 & 465 & 0.23 & 22 \\
14 & 470 & 550 & 455 & 0.22 & 22 \\
\hline
\end{tabular}

properties of the GFRP sheets are given in Table 5. Synthetic resin based adhesive with $1 \mathrm{~g} / \mathrm{ml}$ unit weight was used to apply the GFRP sheets. The application steps of GFRP sheets to the infilled RC frames are given in Figure 3. As seen in the figures, firstly, adhesive was wiped on as a thin layer. After that, a thicker layer of adhesive was applied as a thin layer and the GFRP sheet was placed on the infill wall.

\subsection{Test setup, instrumentation and loading history}

Test setup, loading system and instrumentation are given in Figure 4. The foundations of test specimens were anchored to the strong floor by assembly bars. A servohydraulic actuator was used to apply reversed cyclic lateral loads to the top of the test frames. The applied loading protocol used in the study is given in Figure 5. Lateral loads and top displacements were measured by means of a load cell with $500 \mathrm{kN}$ load measurement capacity and $200 \mathrm{~mm}$ linear potentiometric displacement transducer, respectively. These values were recorded by a data acquisition system to the computer.

\section{Results}

\subsection{Hysteretic responses of test specimens}

General views of test frames under lateral reversed cyclic loading and the hysteretic load-displacement curves of test frames at the end of the test are given in Figures 6 and 7, respectively.

PRCF-1: The hysteretic load-displacement curve of a plane RC frame produced using LSC coded as PRCF-1 is given in Figure 7A. As seen from the figure, the behavior of PRCF-1 is practically symmetrical for pull and push directions. Maximum loads obtained from cyclic loading 


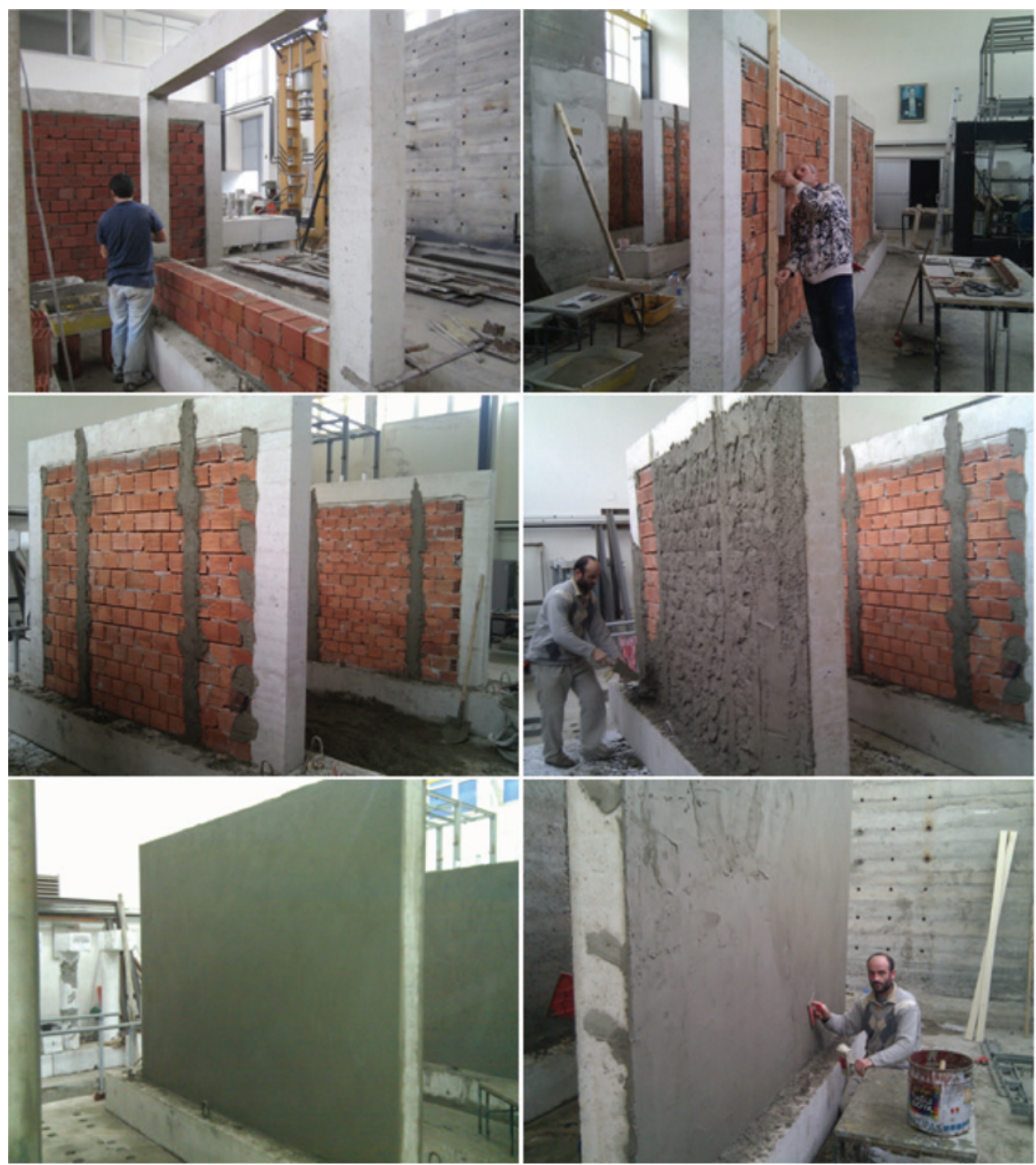

Figure 2: Application of infill wall and concrete plaster.

Table 5: Some physical and mechanical properties of glass fiber reinforced polymer sheet.

\begin{tabular}{lrrr}
\hline $\begin{array}{l}\text { Tensile strength } \\
(\mathrm{MPa})\end{array}$ & $\begin{array}{r}\text { Modulus of } \\
\text { elasticity }(\mathrm{MPa})\end{array}$ & $\begin{array}{r}\text { Unit weight of } \\
\text { area }\left(\mathbf{g} / \mathbf{m}^{2}\right)\end{array}$ & $\begin{array}{r}\text { Thickness } \\
(\mathbf{m m})\end{array}$ \\
\hline 2200 & 70,000 & 510 & 0.5 \\
\hline
\end{tabular}

and corresponding displacements for push and pull are $47.76 \mathrm{kN}-48.51 \mathrm{~mm}$ and $45.08 \mathrm{kN}-49.78 \mathrm{~mm}$, respectively. PRCF-1 reached maximum load carrying capacity at $2.28 \%$ drift ratio. PRCF-1 carried $37 \mathrm{kN}$ load at 3.5\% drift ratio as well.

PRCF-2: Then behavior of a plane RC frame produced using NSC coded as PRCF-2 is similarly symmetrical for pull and push directions like PRCF-1 (Figure 7B). Maximum loads and displacements for push and pull directions of PRFC-2 are $77.61 \mathrm{kN}-44.72 \mathrm{~mm}$ and $71.01 \mathrm{kN}-52.38 \mathrm{~mm}$, respectively. PRCF-2 reached maximum load carrying capacity at $2.10 \%$ drift ratio. PRCF-2 carried $60 \mathrm{kN}$ load at $3.5 \%$ drift ratio as well.

RCF-1: The hysteretic load-displacement curve of a brick infilled RC frame produced using LSC coded as RCF-1 is given in Figure 7C. It is clearly seen from the figure that the behavior of the test frame is almost symmetrical for both directions. Load carrying capacities and corresponding displacements of RCF-1 for push and pull directions are $214.92 \mathrm{kN}-13.08 \mathrm{~mm}$ and $196.39 \mathrm{kN}-12.78 \mathrm{~mm}$, respectively. In addition, RCF-1 reached its maximum load carrying 


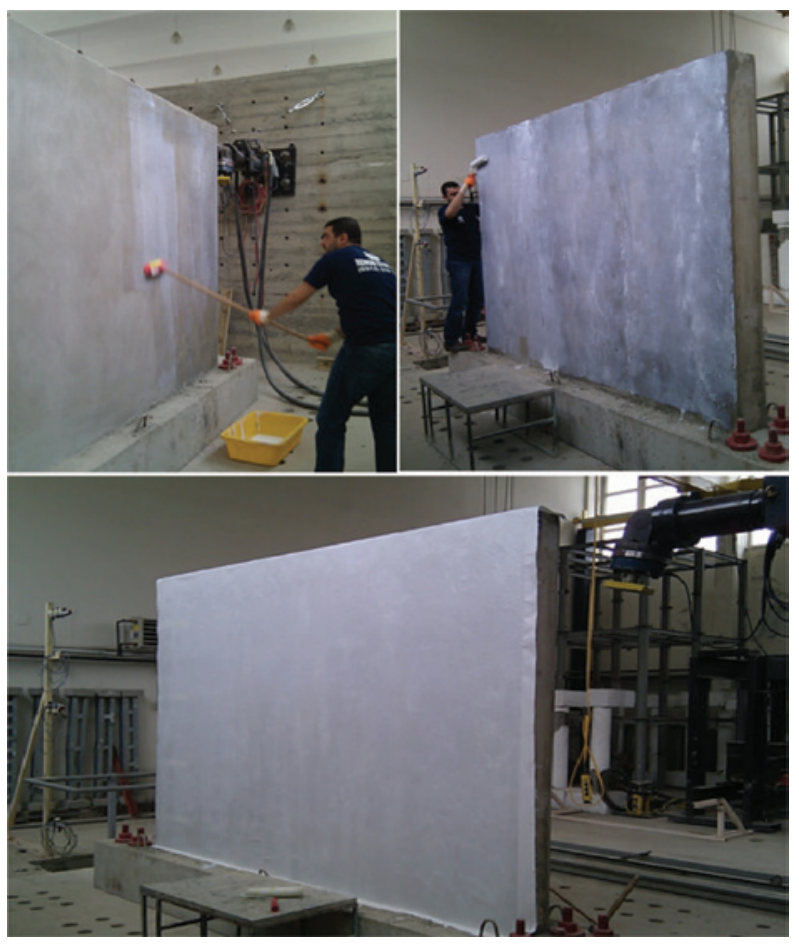

Figure 3: Application steps of glass fiber reinforced polymer sheet to the infilled reinforced concrete (RC) frames. capacity at $0.6 \%$ drift ratio. When loading was kept on, a rapid decrease at load carrying capacity was observed at $1.93 \%$ drift ratio $(115.95 \mathrm{kN})$. RCF-1 carried $52 \mathrm{kN}$ load at $3.5 \%$ drift ratio as well.

RCF-2: The hysteretic response of a brick infilled RC frame produced using LSC and strengthened with a GFRP sheet coded as RCF-2 is given in Figure 7D. The loaddisplacement curve of RCF-2 is also symmetrical for pull and push directions. Maximum loads and displacement for push and pull directions of RCF-2 are $331.32 \mathrm{kN}-25.04 \mathrm{~mm}$

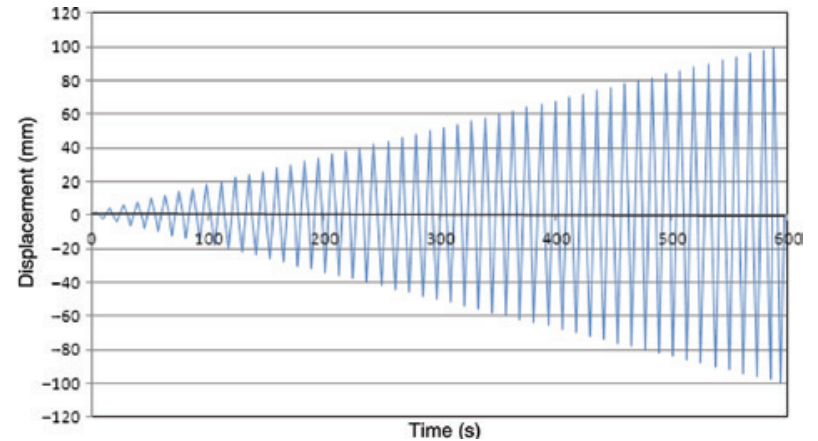

Figure 5: Loading protocol used in the test.

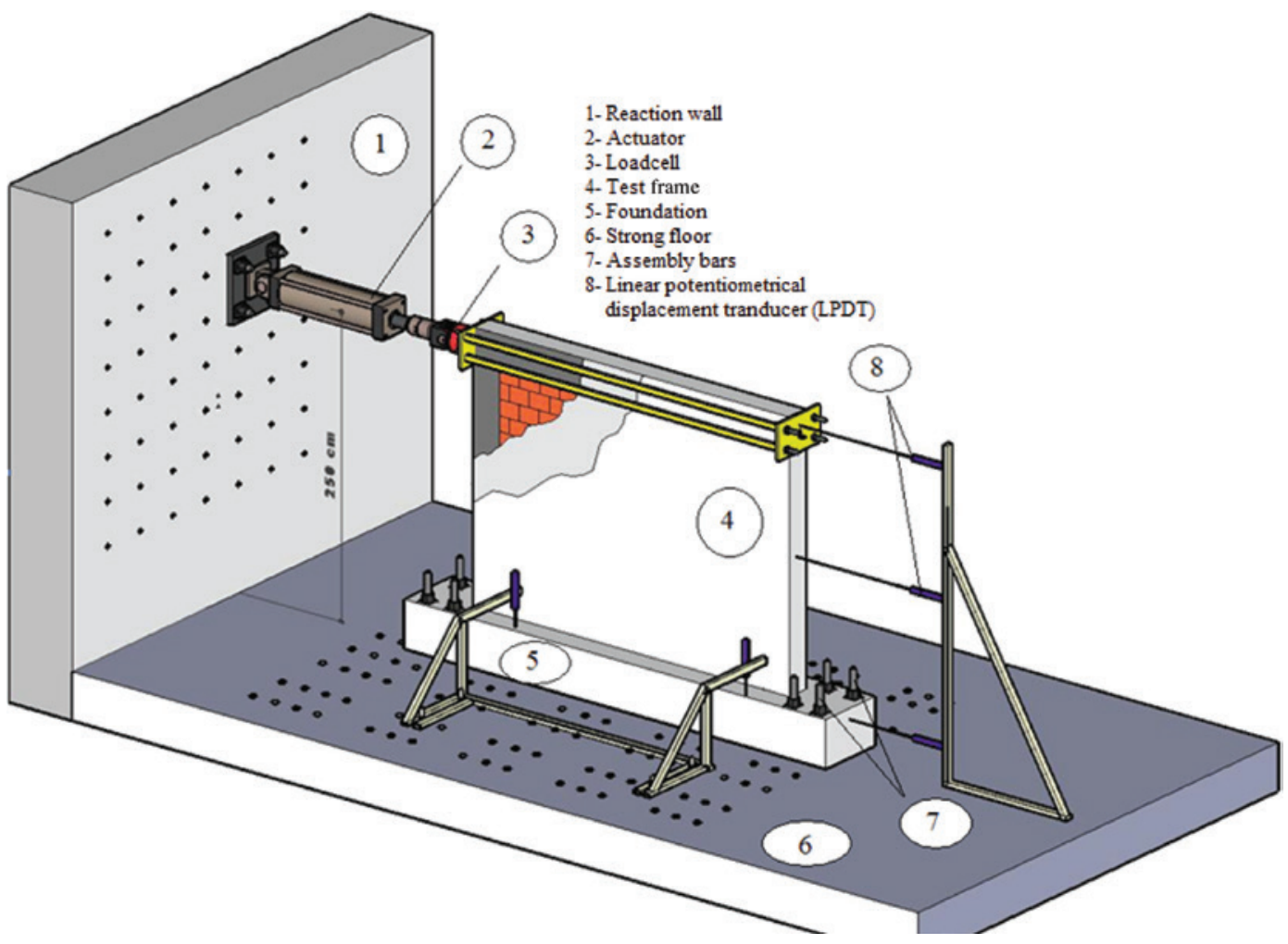

Figure 4: Test set-up of reinforced concrete (RC) frames. 
A

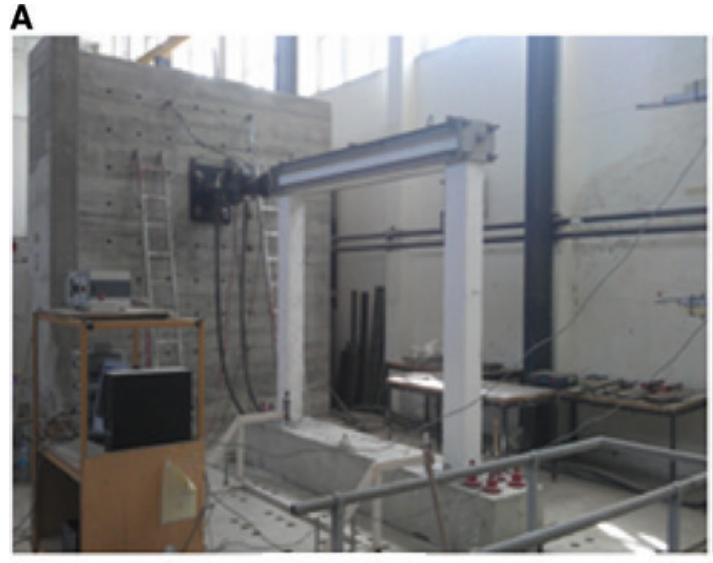

E

B



$\mathbf{F}$
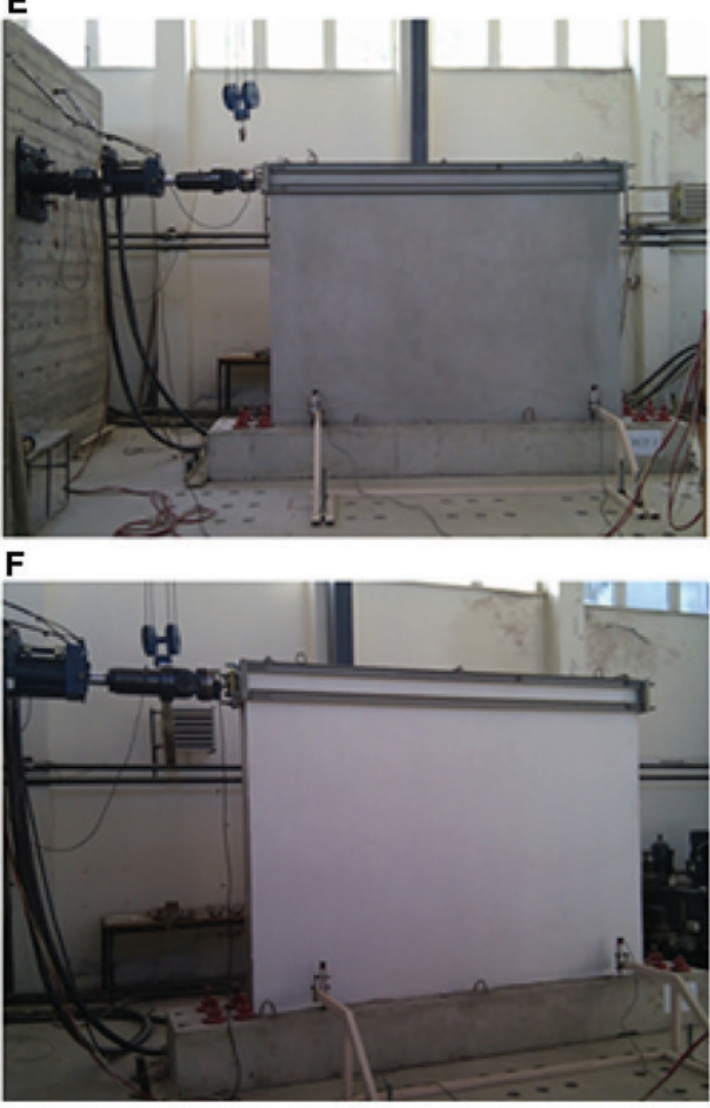

C

G
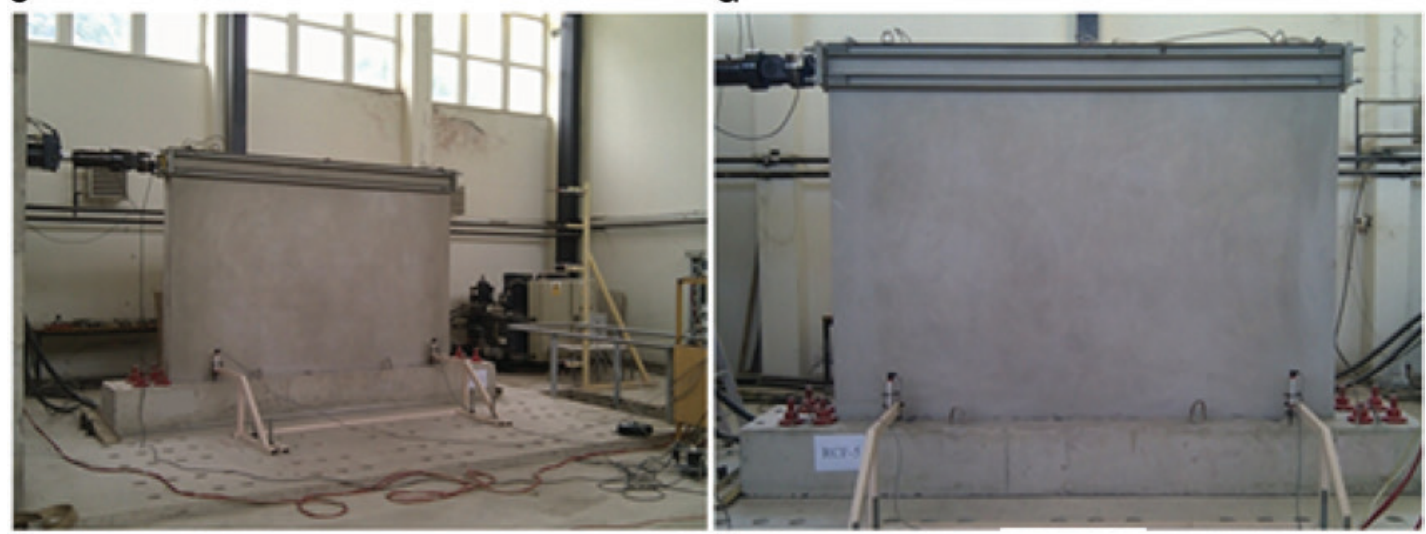

D



H

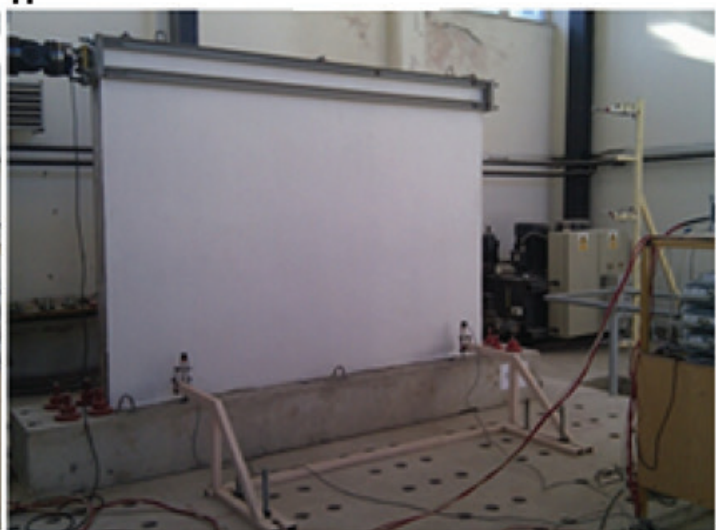

Figure 6: General views of test frames under lateral reversed cyclic loading. (A) PRCF-1, (B) PRCF-2, (C) RCF-1, (D) RCF-2, (E) RCF-3, (F) RCF-4, (G) RCF-5, (H) RCF-6. 

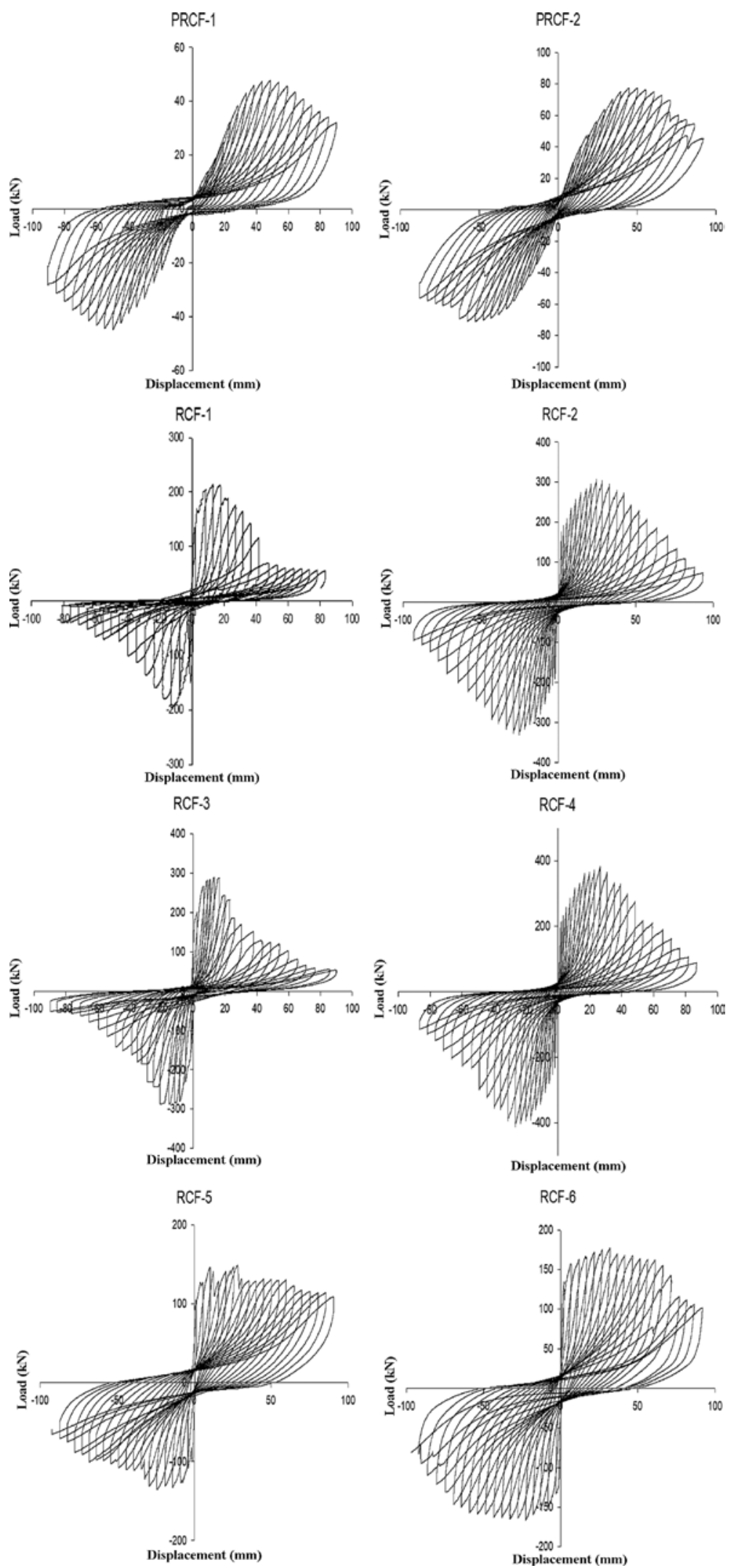

Figure 7: Hysteretic load-displacement curve of test frames. 
and $306.52 \mathrm{kN}-24.72 \mathrm{~mm}$, respectively. The load decrease of RCF-2 after maximum load is more gradual with respect to RCF-1. RCF-2 reached load carrying capacity at $1.18 \%$ drift ratio and at 3.5\% drift ratio, the frame carried $160 \mathrm{kN}$ lateral load.

RCF-3: The hysteretic load-displacement curve of a brick infilled RC frame produced using NSC is given in Figure 7E. The maximum load and displacement obtained from the test for push and pull directions are $289.15 \mathrm{kN}-13.26 \mathrm{~mm}$ and $288.13 \mathrm{kN}-15.16 \mathrm{~mm}$, respectively. The test frame reached its maximum load at $0.71 \% \mathrm{drift}$ ratio. When loading was kept on, the load carrying capacity suddenly decreased at $1.35 \%$ drift ratio (231.314). Also, RCF-3 carried $61 \mathrm{kN}$ load at 3.5\% drift ratio as well.

RCF-4: The hysteretic load-displacement curve of a brick infilled RC frame produced using NSC and strengthened using a GFRP sheet is given in Figure 7F. The maximum load and displacement obtained from the test for push and pull directions are $410.71 \mathrm{kN}-26.77 \mathrm{~mm}$ and $381.71 \mathrm{kN}-26.43 \mathrm{~mm}$, respectively. The test frame reached its maximum load at $1.26 \%$ drift ratio. The load decrease after the maximum load is gradual as in the RCF-2 test frame. In addition, RCF-4 carried an approximately $175 \mathrm{kN}$ lateral load at 3.5\% drift ratio.

RCF-5: Figure $7 \mathrm{G}$ shows that the hysteretic loaddisplacement curve of infilled with aerated concrete block RC frame produced using NSC coded as RCF- 5 is almost symmetrical. The maximum load and displacement obtained from the test for push and pull directions are $148.91 \mathrm{kN}-28.08 \mathrm{~mm}$ and $135.74 \mathrm{kN}-24.13 \mathrm{~mm}$, respectively. The test frame reached its maximum load at $1.14 \%$ drift ratio. The load decrease after the maximum load is more gradual than those of RCF-1 and RCF-3 test frames. In addition, RCF-5 carried an approximately $100 \mathrm{kN}$ lateral load at $3.5 \%$ drift ratio.

RCF-6: The hysteretic load-displacement curve of infilled with an aerated concrete block RC frame produced using NSC and strengthened using GFRP sheets is given in Figure $7 \mathrm{H}$. The maximum loads and displacement obtained from the test for push and pull directions are $177.22 \mathrm{kN}-31.89 \mathrm{~mm}$ and $165.00 \mathrm{kN}-32.94 \mathrm{~mm}$, respectively. The test frame reached its maximum load at $1.50 \%$ drift ratio. RCF-6 had the most gradual load decrease after maximum load and carried approximately $130 \mathrm{kN}$ lateral load at $3.5 \%$ drift ratio.

\section{Discussion}

Test results of plane and GFRP strengthened infilled RC frames with LSC and NSC under lateral reversed cyclic

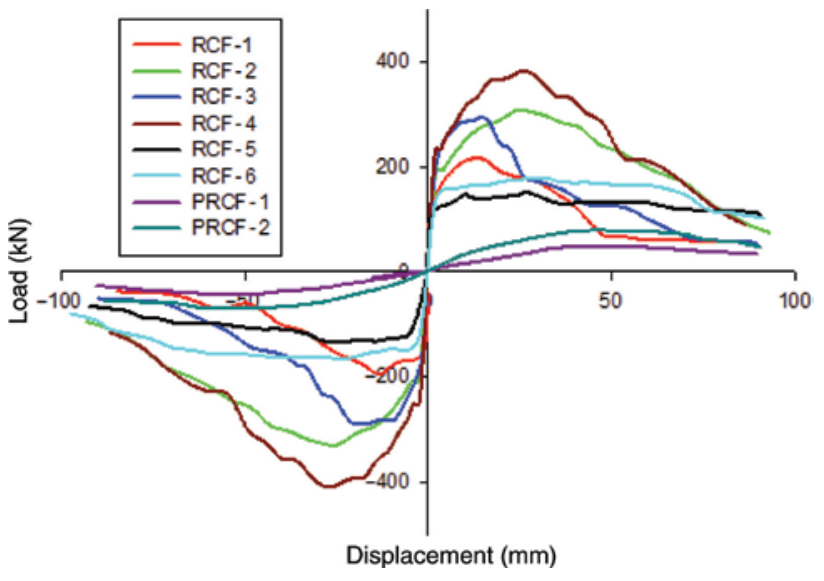

Figure 8: Load-displacement envelope curves of test frames.

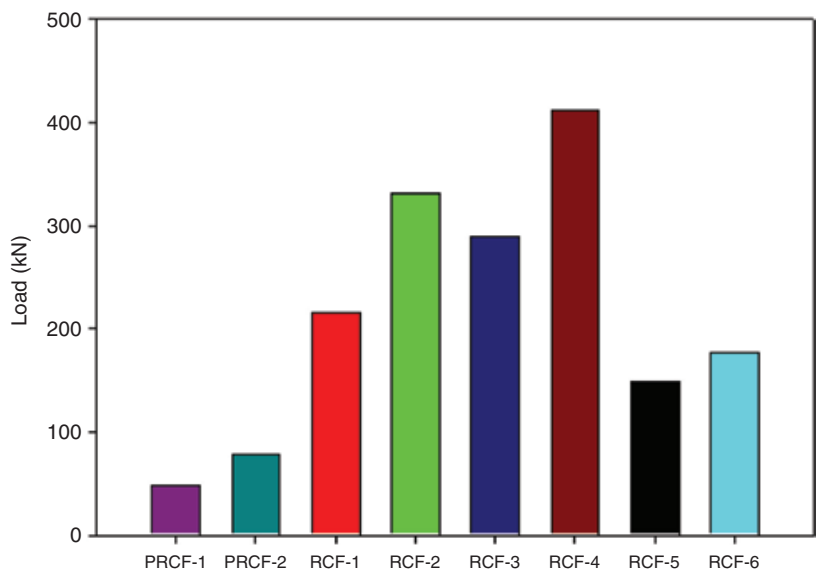

Figure 9: Load carrying capacities of the test frames.

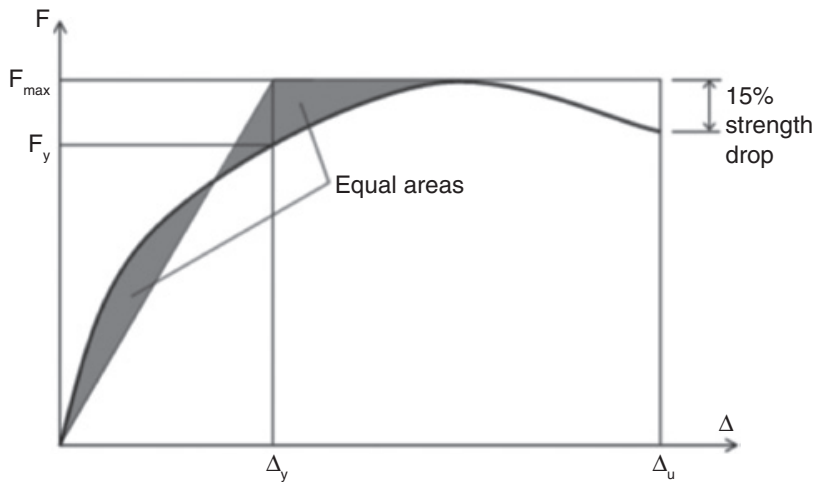

Figure 10: Determination of yield and ultimate displacements according to criteria for equivalent elastoplastic energy absorption.

loading have been discussed in terms of load carrying capacity, energy dissipation capacity, displacement ductility and stiffness degradation. 
Table 6: Displacements at yield and ultimate loads and displacement ductility of the test frames.

\begin{tabular}{llrrrrrrr}
\hline Test frames & Loading directions & $F_{y}(\mathrm{kN})$ & $\mathrm{F}_{\max }(\mathrm{kN})$ & $\mathrm{F}_{\mathrm{u}}(\mathrm{kN})$ & $\mathbf{A}_{\mathrm{y}}(\mathrm{mm})$ & $\boldsymbol{\Delta}_{\max }(\mathrm{mm})$ & $\boldsymbol{\Delta}_{\mathrm{u}}(\mathrm{mm})$ & $\boldsymbol{\Delta}_{\mathrm{u}} / \mathbf{A}$ \\
\hline PRCF-1 & Push (+) & 45.75 & 47.79 & 40.62 & 38.02 & 48.51 & 69.09 \\
& Pull (-) & 42.21 & 45.08 & 38.31 & 37.05 & 49.78 & 67.28 & 1.82 \\
PRCF-2 & Push (+) & 70.02 & 77.61 & 65.97 & 34.06 & 44.72 & 73.21 & 2.15 \\
& Pull (-) & 60.15 & 71.01 & 60.36 & 30.14 & 52.38 & 71.21 & 2.36 \\
RCF-1 & Push (+) & 162.77 & 214.93 & 182.69 & 3.79 & 13.08 & 22.73 & 5.99 \\
& Pull (-) & 161.85 & 196.39 & 166.93 & 3.82 & 12.78 & 23.55 & 6.16 \\
RCF-2 & Push (+) & 208.61 & 306.52 & 260.54 & 5.60 & 24.72 & 42.17 & 7.53 \\
& Pull (-) & 211.17 & 331.32 & 281.62 & 5.51 & 25.04 & 41.70 & 7.56 \\
RCF-3 & Push (+) & 218.07 & 289.15 & 238.13 & 4.01 & 16.54 & 21.26 & 5.30 \\
& Pull (-) & 214.30 & 288.13 & 244.91 & 4.09 & 15.16 & 22.90 & 5.60 \\
RCF-4 & Push (+) & 260.25 & 381.71 & 324.45 & 5.40 & 26.43 & 40.20 & 7.44 \\
& Pull (-) & 279.60 & 410.71 & 349.10 & 5.43 & 26.76 & 40.16 & 7.40 \\
RCF-5 & Push (+) & 123.18 & 148.94 & 126.57 & 3.35 & 28.08 & 35.26 & 10.53 \\
& Pull (-) & 105.90 & 135.74 & 115.38 & 3.81 & 24.13 & 35.73 & 9.38 \\
RCF-6 & Push (+) & 138.51 & 177.22 & 150.64 & 4.16 & 31.89 & 64.58 & 15.52 \\
& Pull (-) & 132.91 & 164.97 & 140.22 & 5.01 & 32.94 & 72.45 & 14.46 \\
\hline
\end{tabular}

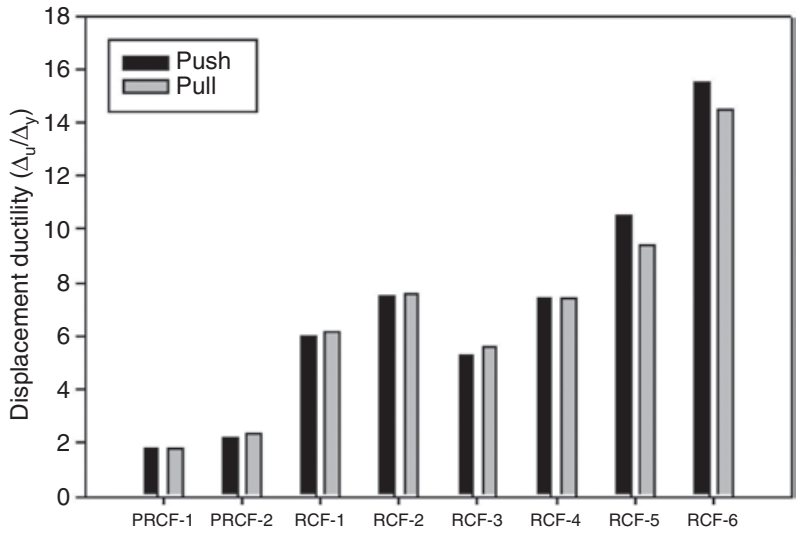

Figure 11: Displacement ductility of the test frames for pull and push directions.

\subsection{Load carrying capacity}

Load-displacement envelope curves of test frames are illustrated in Figure 8. As seen in the figure, infill walls and the GFRP sheets used for the strengthening of test frames considerably increased the load carrying capacity of plane frames. The load carrying capacity increased most for the RCF-4 test frame. This was followed by the RCF-2 test frame. This result shows that infill material significantly affects the RC frame behavior. Although, brick infilled RCF-3, when aerated concrete block infilled RCF-5 and RCF-6 frames were produced using NSC, their load carrying capacities were lower than that of the RCF-2 test frame. A bar graph is given in Figure 9 to see more clearly the load carrying capacities of the test frames.

It was observed during the test that GFRP sheets worked tension diagonally under reversed cyclic loading.

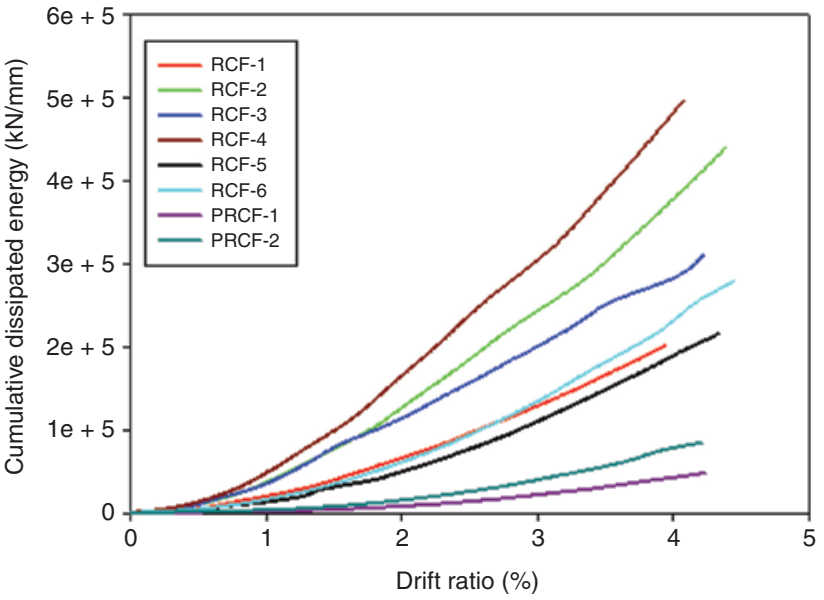

Figure 12: Cumulatively dissipated energy of the test frames.

By contrast, GFRP undertook an important responsibility by preventing brittle failure.

\subsection{Displacement ductility}

The displacement ductility is the ratio of the maximum deformation that a structure or element can undergo without a significant loss of initial yielding resistance to the initial yield deformation. However, it was not easy to determine yield points for the specimens directly from the lateral load-displacement curves. For each specimen, the load-displacement envelope curve was used to define the yield and maximum displacements according to the criteria for equivalent elastoplastic energy absorption used by Park [26] as seen in Figure 10. The ultimate displacement $\Delta_{\mathrm{u}}$ corresponded to a $15 \%$ drop of the peak load. 
The displacement ductility was calculated from the ratio of ultimate displacement to yield displacement $\Delta_{\mathrm{u}} / \Delta_{\mathrm{y}}$ [26-28]. Displacements at yield, maximum and ultimate loads and displacement ductility of test specimens are shown in Table 6 and Figure 11.

When the displacement ductility values under cyclic loading were analyzed, the highest ductility was obtained for RCF-5 and RCF-6 which had lower load carrying capacity than those of brick infilled RC frames.

\subsection{Energy dissipation capacity}

Total dissipated energy was calculated by cumulatively collecting the areas underneath the load-displacement curve for each cycle. The cumulative energy dissipation capacities of the test frames at a particular drift ratio are shown in Figure 12.

As seen in Figure 12, the dissipated energy was small in the elastic stage. When the test frames reached the elastoplastic stage, the amount of the dissipated energy of the test frames increased with increasing damage. After reaching the peak load, the load-carrying capacity of the test frames began to decrease gradually, but the energydissipation capacity still slowly increased. As seen in the figure, infill walls increased the energy dissipation capacity of the plane frames. The highest energy was dissipated for the RCF-4 test frame and this was followed by the RCF-2 test frame. These results reveal the importance of GFRP sheets and the material used for producing infill walls with regard to frame behavior. The dissipated energies of the $\mathrm{RC}$ test frames at 3.5\% drift ratio are given in Figure 13.

\subsection{Stiffness degradation}

Stiffness degradation is a parameter used to evaluate the overall response of specimens. In order to assess stiffness

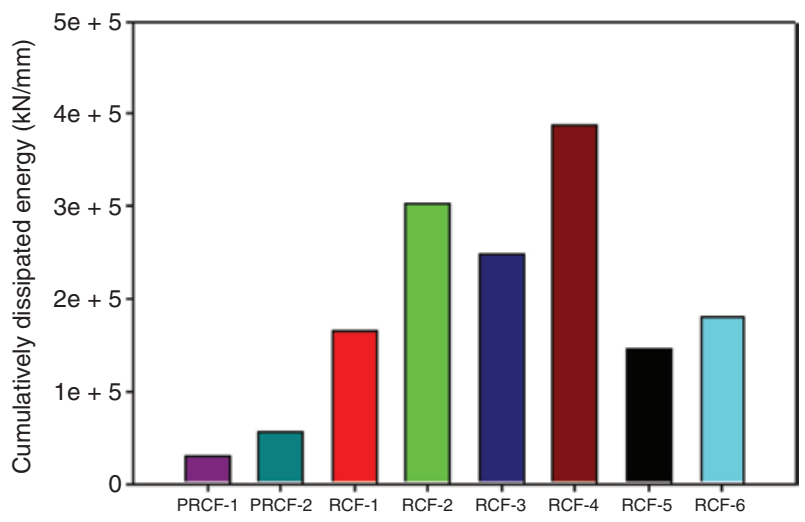

Figure 13: Cumulatively dissipated energy at 3.5\% drift ratio level.

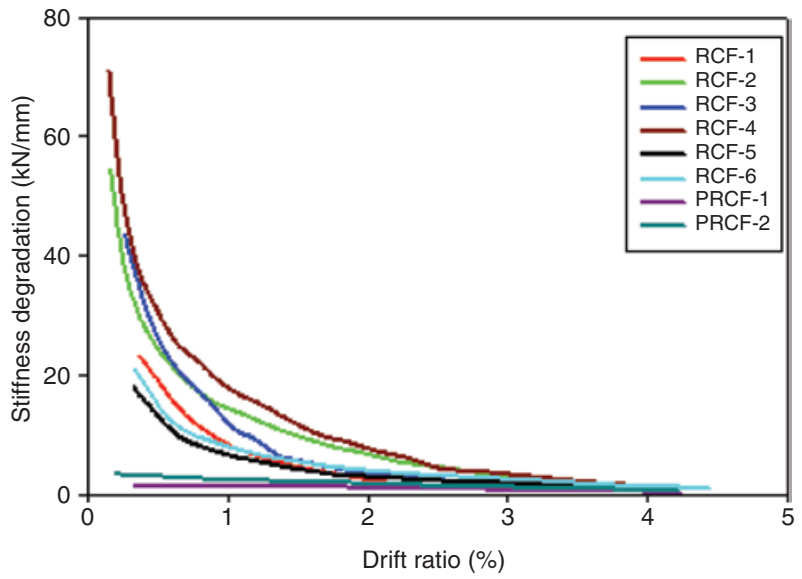

Figure 14: Stiffness degradation of the test frames.

degradation, the secant stiffness was computed for each loading cycle at a particular drift level. The secant stiffness was calculated using a straight line between the maximum load and corresponding displacement points for the positive and negative directions in a load cycle. Stiffness degradation-drift ratio curves of the test frames are given in Figure 14. It is clearly seen from the curves that stiffness of the RC test frames continuously decrease with increasing drift ratio, as cumulative damage in the frames increases throughout the test. In addition, each frame experienced severe stiffness degradation at the end of the test. By contrast, initial stiffness of the test frames is given in Figure 15. As seen in the figure, the highest initial stiffness occurred in the RCF-4 test frame.

\subsection{Failure patterns of the test frames}

The failure pattern of infilled frames under cyclic loading can differ by span/height ratio. In this study, brick

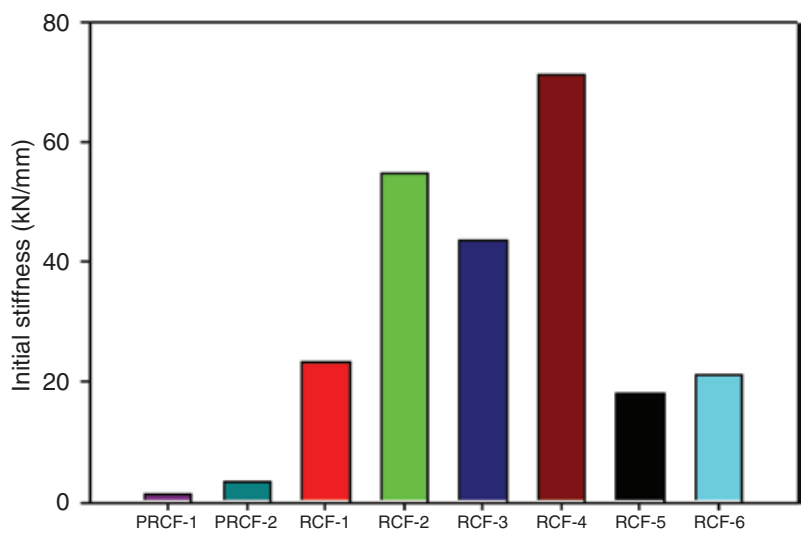

Figure 15: Initial stiffness of the test frames. 
A

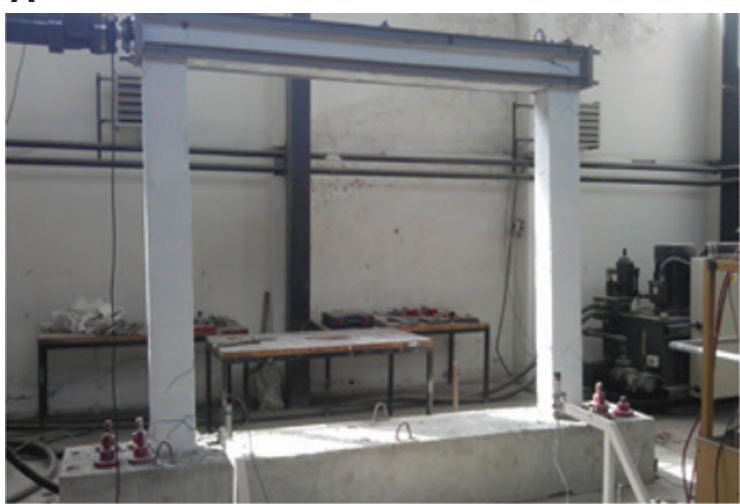

E

B
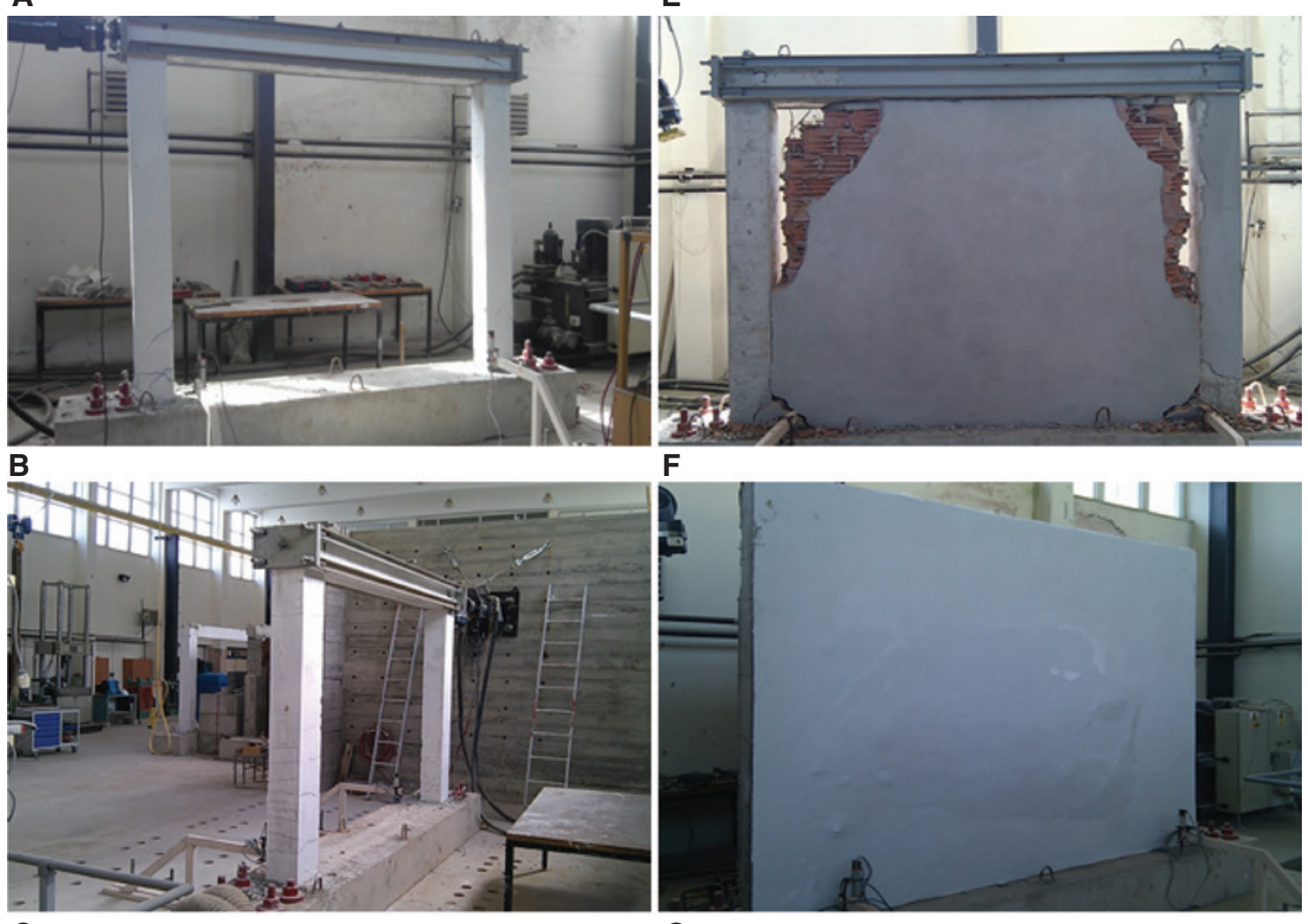

$\mathbf{F}$

\section{C}


G


H



Figure 16: Failure patterns of the test frames. (A) PRCF-1, (B) PRCF-2, (C) RCF-1, (D) RCF-2, (E) RCF-3, (F) RCF-4, (G) RCF-5, (H) RCF-6. 
infilled RCF-1 and RCF-3 test frames lost their load carrying capacities by crushing of infill walls, cover and core concrete around beam-column and column-base joints. Even if diagonal cracks occurred for the aerated concrete infilled RCF-5 test frame, the infill wall did not overturn out of the plane direction of the frame. Brick infill walls were crushed under reverse cyclic loading, but none of the brick remained dispersed around owing to the GFRP sheet for RCF- 2 and RCF-4 test frames. The crack pattern of RCF-6 is similar to the RCF-5 test frame. By contrast, crack amount increased for the test frames strengthening with GFRP and accordingly, crack widths decreased, whereas, damage to the plane and non-strengthened RC frames centered on the lower end of the column, and cracks distributed uniformly throughout the columns. Failure patterns of the test frames are seen in Figure 16.

\section{Conclusions}

This paper presents the experimental behavior of plane and GFRP strengthened infilled RC frames with LSC and NSC under lateral reversed cyclic loading. For this purpose, eight full-scale, one-bay, one-storey plane and infilled (brick and aerated concrete blocks) RC frames with LSC and NSC were produced and loaded laterally. Based on the test results of this study, the following conclusions can be made:

1. GFRP sheets used for strengthening of infilled RC frames with LSC and NSC under lateral reversed cyclic loading considerably increased load carrying capacity, energy dissipation capacity and displacement ductility. In addition, GFRP sheets prevented dispersal around the remains of the infill wall. These results indicate that GFRP sheets used for strengthening contribute to preventing loss of life and properties.

2. When the initial stiffness, load carrying and energy dissipation capacities of the RC frames are all evaluated together, the RCF-4 infilled frame has the best performance such that load carrying capacity, energy dissipation capacity and initial stiffness value of the RCF-4 frame are higher than those of other test frames $24 \%-760 \%, 28 \%-1165 \%$ and 1.356 times, respectively.

3. Load carrying capacities of brick infilled RC frame produced using LSC coded as RCF-1 and brick infilled RC frame produced using LSC and strengthened with GFPR sheets coded as RCF-2 are approximately $21 \%-122 \%$ higher than RC frames infilled with aerated concrete block produced using NSC (RCF-5) and strengthened with GFPR (RCF-6). This result shows that choosing infill material is very important to obtain a higher load carrying capacity.

4. The highest displacement ductility is obtained for the RCF-6 frame. This result shows that infill walls with aerated concrete blocks contribute to the ductility of the $\mathrm{RC}$ frames.

\section{References}

[1] Arslan ME. Experimental and Theoretıcal Investigation of Behavior of In-filled RC Frames Strengthened with GFRP Under Cyclıc Loading [Ph.D]. Karadeniz Technical University: Turkey, 2013.

[2] Garcia R, Hajirasouliha I, Pilakoutas K. Eng. Struct. 2010, 32, 3075-3085.

[3] Pendhari SS, Kant T, Desai YM. Compos. Struct. 2008, 84, 114-124.

[4] Seifi A, Hosseini A, Marefat MS, Zareian MS. Eng. Struct. 2017, $147,705-723$.

[5] Gdoutos EE, Pilakoutas K, Rodopoulos C. Failure Analysis of Industrial Composite Materials, 1st ed., McGraw-Hill: New York, 2000.

[6] Balsamo A, Manfredi G, Mola E, Negro P, Prota A. Eng. Struct. 2005, 27, 769-780.

[7] Altin S, Anil Ö, Kara ME, Kaya M. Composites, Part B 2008, 39, 680-693.

[8] Prota A, Nanni A, Manfredi G, Cosenza E. ACl Struct. J. 2004, 101, 699-707.

[9] Corte G, Barecchia E, Mazzolani F. J. Mater. Civ. Eng. 2006, 18, 659-669.

[10] Di Ludovico M, Manfredi G, Mola E, Negro P, Prota A. J. Struct. Eng. 2008, 134, 810-821.

[11] Erdem I, Akyuz U, Ersoy U, Ozcebe G. Eng. Struct. 2006, 28, 1843-1851.

[12] Farahbod F, Mostofinejad D. Compos. Struct. 2011, 93 , 1168-1177.

[13] Ozsayin B, Yilmaz E, Ispir M, Ozkaynak H, Yuksel E, Ilki A. Constr. Build. Mater. 2011, 25, 4017-4024.

[14] Popescu C, Schmidt JW, Goltermann P, Sas G. Eng. Struct. 2017, 150, 585-598.

[15] Moshiri N, Hosseini A, Mostofinejad D. Constr. Build. Mater. 2015, 79, 318-325.

[16] Esmaeeli E, Danesh F, Tee KF, Eshghi S. Compos. Struct. 2017, 159, 206-219.

[17] FEMA356. Prestandard and Commentary for the Seismic Rehabilitation of Buildings. Federal Emergency Management Agency: Washington, DC, 2000. 
[18] FEMA440. Improvement of Nonlinear static Seismic Analysis Procedures. Federal Emergency Management Agency: Washington, DC, 2005.

[19] Attari N, Amziane S, Chemrouk M. Constr. Build. Mater. 2012, $37,746-757$.

[20] Jariwala VH, Patel PV, Purohit SP. Procedia Eng. 2013, 51, 282-289.

[21] Panda KC, Bhattacharyya SK, Barai SV. Constr. Build. Mater. 2013, 41, 79-90.

[22] Panigrahi AK, Biswal KC, Barik MR. Constr. Build. Mater. 2014, 57, 81-91.
[23] Sen T, Jagannatha Reddy HN. Int. J. Sustainable Built Environ. 2013, 2, 41-55.

[24] Del Vecchio C, Di Ludovico M, Prota A, Manfredi G. Compos. Struct. 2016, 142, 107-116.

[25] TSDC2007. Turkish Seismic Design Code. Ministry of Public Works: Ankara, 2007.

[26] Park R. Bull. New Zealand Nat. Soc. Earthquake Eng. 1989, 22, 55-166.

[27] Pul S, Hüsem M, Arslan ME, Hamzaçebi S. Comput. Concr. 2014, 13, 377-387.

[28] Xue W, Yang X. PCl J. 2010, 55, 102-121. 